\begin{tabular}{c} 
Volume and Issues Obtainable at Center for Sustainability Research and Consultancy \\
Responsible Education, Learning and Teaching in Emerging Economies \\
ISSN: 2708-4310 (E): 2708-4183 \\
Volume 2: No.1, June 2020 \\
CSRC \\
Journal homepage: www.publishing.globalcsrc.org/relate \\
\hline
\end{tabular}

\title{
Psychological Problems Faced by Educational Managers of Public Schools after Rehabilitation in South Waziristan Tribal District (SWTD)
}

\begin{abstract}
${ }^{1}$ Niaz Muhammad, ${ }^{2}$ Shabnam Bibi
${ }^{1} \mathrm{PhD}$ Scholar, Allama Iqbal Open University, Islamabad, Pakistan, niazk1981@gmail.com

${ }^{2}$ Assistant Professor Department of Education, University of Lahore, Pakistan, shabnirehman@ gmail.com ARTICLE DETAILS ABSTRACT

History

Revised format: May 2020

Available Online: June 2020

Keywords

Management, Rehabilitation,

Psychological problems, Public

Schools

JEL Classification:

I20, I23

This study aimed, psychological problems of educational managers which they faced after rehabilitation of IDPs, when schools opened in the terrorism affected areas. The research study was descriptive in nature and mixed method approach was used. Therefore whole population of 92 schools' managers was selected from the areas of South Waziristan Agency, declared open by the government of Pakistan after operation for repatriation. The sample consisted of 92 heads of educational institutions and 24 Maliks from those schools, numbers of respondents were 116 under this study. Questionnaire was developed for AEO, AAEOs, Principals, Headmasters/Headmistresses of middle schools and primary schools' Head teachers and interview was scheduled for the Maliks. Collected data was analyzed considering the objectives and research questions of the study. The descriptive statistics was used for questionnaire data analysis. Thematic analysis technique was used for interview data analysis and open ended section of questionnaire. Findings revealed that the respondents were facing problems i.e., Fear of concealed mining bombs, students and teachers behavior was non cooperative, past traumatic events was creating chaos, parents and community did not take interest because of financial problem and they kept children in domestic tasks. It was concluded that areas may be cleared properly avoiding mining blasts, seminars and refreshment opportunities are arranged for removing fear from their hearts, donors may be encouraged to support the educational institutions.
\end{abstract}

(C) 2020 The authors, under a Creative Commons AttributionOPEN ACCESS NonCommercial 4.0

Corresponding author's email address: niazk1981@gmail.com

Recommended citation: Muhammad, N. \& Bibi, S. (2020). Psychological Problems Faced by Educational Managers of Public Schools after Rehabilitation in South Waziristan Tribal District (SWTD). Responsible Education, Learning and Teaching in Emerging Economies, 2(1), 37-48.

\section{Introduction}

After the attacks of 9/11 US announced war on terrorism. A chain of operations was started in Pakistan by Pakistani military being first line ally to USA in war against terrorism. Pakistan army started an operation known as "Rah-eNijat" that began on June 19, 2009, in Agency of South Waziristan (Javid, 2015). After completion of military operation, government declared the area opened and the process of rehabilitation started. This study was designed to see the problems of educational managers after rehabilitation in the area of South Waziristan Agency which is declared open by the government of Pakistan. 
Education sector was affected badly in war of terrorism in South Waziristan Agency. Education is one of the most important agents for overall development of any nation today (Sultana, 2015). It is proved in 1960s by Schultz and Becker in their pioneer works that for economic growth it is very necessary that majority of the citizens are literate. Government of Pakistan has been attempting from the past to identify different problems of educational management and also Government of Pakistan worked to provide measures to overcome those educational problems. Hence, still millions of school age children are out of school (Khan, 2013).

Education management is facing many problems in infrastructure, teacher training, recruitment, access to schools, equal opportunity, quality and budgeting at every level (Aziz, Bloom, Humaira, Jimenez, Rosenberg, Sather, 2014). In these regard, areas like FATA remains more far behind in educational facilities. In Rah-e-Nijat military operation educational system and infrastructure adversely affected in FATA. FATA is located along Afghanistan border consisting of seven Agencies of South Waziristan, North Waziristan, Orakzai, Khyber, Kurram, Bajaur, Mohmand and six Frontier Regions of Bannu, Peshawar, Dera Ismail Khan, Kohat, Laki Marwat, and Tank(Naqvi, khan, Ahmad, 2012).

In three sub-divisions of South Waziristan Agency (SWA) the numbers of functional schools are 296 (40 \%) out of 741 while nonfunctional schools are 445 (60\%) out of 741 including primary, middle, high Mosque/Maktab Schools, IHC, community schools/developmental package schools (source : Education Management Information System (EMIS) cell SWA, 2016). On the other hand literacy rate is as under:

Table 1

Literacy rate of South Waziristan Agency

\begin{tabular}{|c|c|c|c|}
\hline Year & $\begin{array}{l}\text { Male Literacy } \\
\text { rate in \% }\end{array}$ & $\begin{array}{l}\text { Female Literacy rate } \\
\text { in } \%\end{array}$ & $\begin{array}{l}\text { Both sexes Literacy rate } \\
\text { in } \%\end{array}$ \\
\hline 1981 & 11.8 & 0.6 & 7.0 \\
\hline 1998 & 32.5 & 2.6 & 19.8 \\
\hline 2007 & 32.3 & 4.3 & 20.61 \\
\hline
\end{tabular}

Sources: $\quad$ i- 1998 Census Report of SWA. $\quad$ ii- $\quad$ FATA Development Statistics 2012.

In South Waziristan Agency, Malik system works. Maliks are those persons who are privileged by the government on condition of the assurance of loyalty to Pakistan (Awan, 2013). Maliks are the influential persons, the community leaders/elders and the owners of the public schools. They can influence the transfers and other managerial activities. Therefore, they are considered to be under the umbrella of managers also.

\section{Objectives of the study}

1. To explore and prioritize psychological problems faced by educational managers after rehabilitation of IDPs in SWTD (South Waziristan Tribal District).

2. To Find out the possible ways to solve identified problems faced by educational managers on permanent bases according to the local circumstances with the help of stakeholders.

\section{Research Questions}

1. What psychological problems faced by educational managers?

3. Which identified educational managers' problems need solution on top priorities?

4. What are the possible solutions to the problems faced by educational managers?

\section{Literature Review}

Educational management is the key agent of any policy, plan, program, and project implementation. Managers are the persons who implement policy, plan, program and project.

\section{Introduction Of South Waziristan Tribal District}

Waziristan can be administratively separated into two areas, South Waziristan Tribal District (SWTD) and North Waziristan Tribal District (NWTD). In FATA Federal Administered Tribal Area) the largest agency is SWA, now 
South Waziristan Tribal District after merging into KPK. Further the District of South Waziristan is separated into three executive parts of Sarwakai, Ladha and Wana. These three parts are further separated into eight tehsils: Toi khullah, Sararogha Makin, Sarwakai, Wana, Tiarza, and Ladha. South Waziristan has two head office; winter season headquarter is in Tank while Wana headquarter is for summer season. There are two main tribes in the South Waziristan Agency known as Mehsud and Wazir (Mehsud and Israr, 2014).

\section{Malik and Rewaj}

The Pakistani government oversees each agency through a political agent. An assistant political officer/assistant political agent governs each sub-division and political tehsildars oversee each tehsil. The Maliks system provides another layer of traditional governance between the central administration and the individual tribe member. A malik is a hereditary intermediary between the tribe and the agency administration. The Lungi system or Sufaid Resh is a lower form of malik.

According to Naqvi, Khan and Ahmad (2012) all criminal and civil nature cases in Waziristan are guided by customary law called Rewaj, which is outlined by the Frontier Criminal Rules in 1901. This code governs the procedures for both criminal and civil cases. Political disputes are resolved by decisions derived by jirgas or councils of local elders. Waziristan's current political administration is similar to the British system prior to $1947 . \quad$ The Pakistani government left the traditional structure in place to help ensure the loyalty of the tribes. Pakistan also adopted a "Close Border" policy and limited interference in tribal affairs. The nascent Pakistani government used a political agent to maintain relations with the tribes.

\section{Terrorism}

According to the Global Terrorism Database terrorism may be defined as the "threatened or actual use of illegal force and violence by a non-state actor to attain a political, economic, religious, or social goal through fear, coercion, or intimidation" (Codebook, 2016).

\section{Operation Rah-e-Nijat Impact on FATA Education}

Operation Zalzala failure became very evident as Baitullah Mehsud ran a current of terror in the years 2008 and 2009 from his base in South Waziristan. Pakistan army started fourth army operation called "Rah-e-Nijat", on October 17, in 2009; about 30, 000 Pakistani soldiers sent to South Waziristan for the purpose to war against militants. Operation Rah-e-Nijat had several objectives, which were containing the aims to safe key lines of communications, terrorists' places infrastructure destruction in that area. Both the Pakistani Air Force and Army deal this operation with the coordination of United States. (Ali, 2010).

Militants attacked and destroyed a number of boys and girls schools in FATA and KPK as a strategy to imbue the youth of the area with militant values. A 2010 UNESCO report describes incidents occurring between 2007 and 2009 where teachers were shot, children were injured or killed by bombs detonated at schools, and children were kidnapped from their schools by the Taliban (UNESCO, 2010). Media reports claimed that the terrorist attacks resulted in considerable disruption to education throughout the region, although the accounts provide conflicting information on the number of schools damaged or destroyed (Saqib \& Ahmad, 2014). For example, one report claimed that 900 government and private schools were closed and girls' enrolment fell from 120,000in 2007 to just 50,000 in 2009 (Hussain, 2016). Another report concluded that 116 girls' schools and 56 boys' schools were destroyed or damaged between 2007 and March 2009 in Swat alone (Ahmad, 2012). Another report claimed that the Taliban destroyed over 800 schools throughout KPK and over 400 in Swat alone (Khan \& Seltzer, 2016).

\section{Educational management in SWTD}

Educational management structure at Agency/FR level is illustrated in the following figure. 


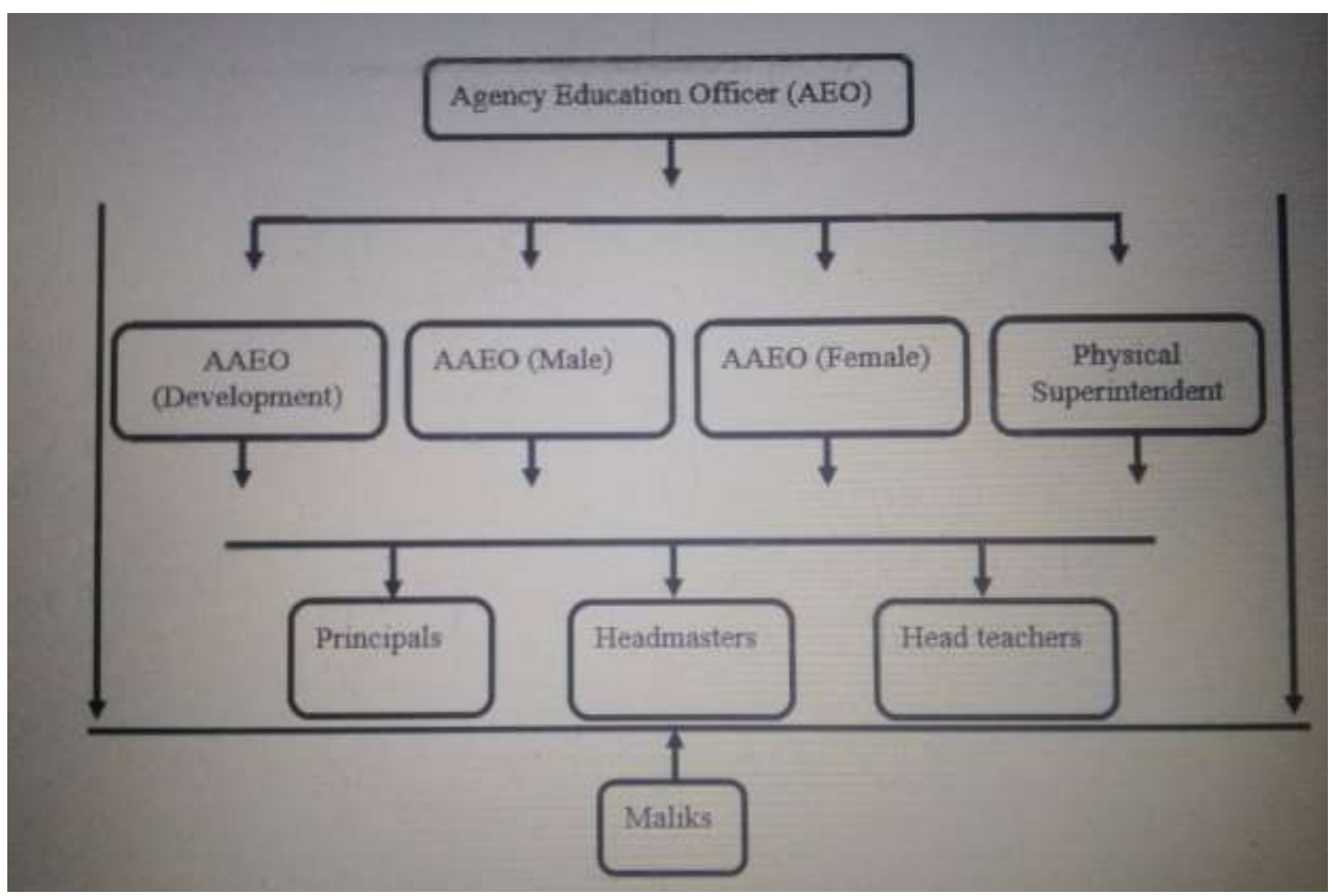

Figure 3 Source, FATA directorate of education official web page (https://www.fata.gov.pk) \& partial Authors' compilation

The above figure is drawn from the source of FATA directorate of education official web page with desired authors' compilation. AEO is the head of the Agency/FR Education department while AAEOs assist and deal different sections of the education department. Principals, headmasters/headmistresses and head teachers head the educational institution. In this study the figure of Malik is added from the literature, as the Maliks i.e. the community elders and representatives who have great influence on all the activities and policies from the government and they have great influence on government decision making. Although they are not educational managers properly, but indirect they exercise more powers than educational managers, therefore they influence and functions of educational management (Masood, 2012). They have influence on AEO, AAEOs, Principals, Headmasters and Head teachers. Therefore they are also included in the study as educational managers.

\section{Psychological Problems}

Terrorism is a form of psychological warfare against a society. It is designed to strike fear into the heart of the targeted society, and it generally succeeds in doing so. Suicide terrorism can be particularly effective in terrifying people because it projects an aura of fanaticism, which makes the threat of future attacks seem more likely. (Malhotra, 2017) Wazir (2014) identified some major issues like insecurity, ruined infrastructure, education, unemployment, psychological problems, and shortage of food and health facilities in her research.

\section{Methodology}

This study was descriptive in nature and mixed method approach was used for this research study. Blend of quantitative and qualitative techniques for data collection and analysis was used. The design used for this mixed method approach was Convergent parallel design.

\section{Sample Size and Sampling Technique}


The whole population i.e. $100 \%$ population of study was included in this research for data collection. AEO, all AAEOs, Principals, Headmasters/Headmistresses, Head teachers and Maliks of the area declared open after military operation (Rah-e-Nijat) were the population of this research study, and all of them were included as census. The population of this research study was taken from the area which was declared opened in first phase. Population of this research study comprised of 92 heads of educational institutions and 24 Maliks. Therefore total numbers of respondents' were 116.

\section{Research Instrument}

The researcher developed the questionnaire for data collection from AEO, AAEOs, Principals, headmasters/headmistress and head teachers. A semi-structured interview was developed by the researcher for data collection from Maliks. The items of these instruments were developed through reviewing the related literature and identifying the construct, sub constructs and indicators of the psychological problems. Psychological problems are internal mechanism and are related to covert behavior. The effects are related to one self and situation of mind. When these psychological problems converted into overt behavior then the people in society are also affected with some specific behavior displayed in community. Now this state of problem comes under the umbrella of social problems.

\section{Data Collection and Data Analysis Procedure}

\subsection{Analysis of Questionnaire Data}

Questionnaire contained 16 items. The responses to the items are presented in the following tables.

Table 1

Fear due to previous evidences of terrorism

\begin{tabular}{llllll}
\hline Statement & Level & $\mathrm{N}$ & $\%$ & $\mathrm{M}$ & SD \\
\hline I feel fear due to previous & SDA & 7 & 7.6 & & \\
evidences of terrorism in my area. & DA & 10 & 10.9 & 3.5761 & 0.9859 \\
& UND & 0 & 0 & 79.3 & \\
& A & 73 & 2.2 & \\
\hline
\end{tabular}

Table 1 shows that out of 92 respondents $75(73+2), 81.5 \%$ of the respondents agreed with the statement that they feel fear due to previous evidences of terrorism in the area. Seventeen $(10+7), 18.5 \%$ of them disagreed with the statement. The mean score 3.57 and the $\mathrm{SD}=0.98$ indicate that majority of the respondents feel fear due to previous terrorist activities.

Table 2

Feeling fear of mining bombs

\begin{tabular}{lcllll}
\hline Statement & Level & N & $\%$ & M & SD \\
\hline I feel fear of mining & bombs SDA & 7 & 7.6 & & \\
concealed in the area & DA & 4 & 4.3 & & \\
& UND & 0 & 0 & 4.1739 & 1.15415 \\
& A & 36 & 39.1 & & \\
& SA & 45 & 48.9 & & \\
\hline
\end{tabular}

Table 2 shows that out of 92 respondents $81(45+36), 88 \%$ of the respondents agreed with the statement that they feel fear of mining bombs concealed in the area. Eleven $(7+4) 11.9 \%$ of them disagreed with the statement. The mean score $4.17, \mathrm{SD}=1.15$ indicates that majority of the respondents feel fear of mining bombs concealed in the area.

Table 3

Past traumatic events create chaos

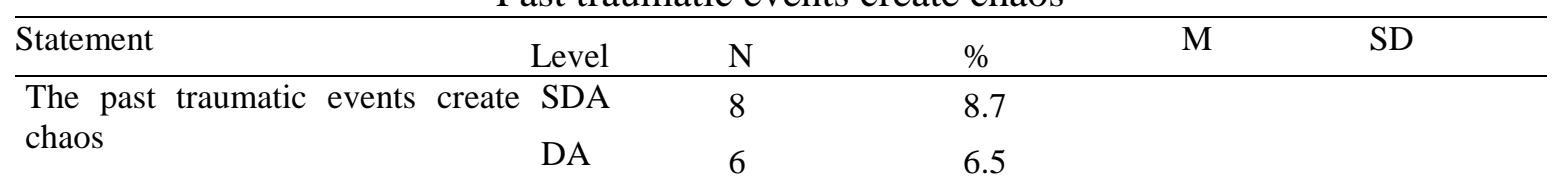




\begin{tabular}{lllll} 
UD & 6 & 6.5 & 3.6522 & 1.05283 \\
A & 62 & 67.4 & & \\
SA & 10 & 10.9 & & \\
Total & 92 & 100.0 & & \\
\hline
\end{tabular}

Table 3 shows that out of 92 respondents $72(62+10), 78.3 \%$ of the respondents agreed with the statement that the past traumatic events create chaos. Fourteen $(15.2 \%)$ of respondents disagreed with the statement and $6(6.5 \%)$ remained undecided. The mean score $3.65, \mathrm{SD}=1.05$ indicate that in majority of the respondents the past traumatic events create chaos.

Table 4

Feeling threats of terrorism

\begin{tabular}{llllll}
\hline Statement & Level & N & $\%$ & M & SD \\
\hline I still feel threats of terrorism. & SDA & 9 & 9.8 & & \\
& DA & 12 & 13.0 & & \\
& UD & 1 & 1.1 & 3.4348 & 1.05147 \\
& A & 70 & 76.1 & & \\
& SA & 0 & 0 & & \\
& Total & 92 & 100.0 & & \\
\hline
\end{tabular}

Table 4 shows that out of 92 respondents $70(70+0), 76.1 \%$ of the respondents agreed with the statement that they still feel threats of terrorism. Twenty-one (12+9), $22.8 \%$ of them disagreed with the statement and 1 respondent (1.1\%) remained undecided. The mean score $3.43, \mathrm{SD}=1.05$ indicates that majority of the respondents still feel threats of terrorism.

Table 5

Threats of starting conflict again

\begin{tabular}{|c|c|c|c|c|c|}
\hline \multirow{2}{*}{$\begin{array}{l}\text { Statement } \\
\text { I feel threats of conflict again }\end{array}$} & Level & \multirow{2}{*}{$\begin{array}{l}\mathrm{N} \\
10\end{array}$} & \multirow{2}{*}{$\begin{array}{l}\% \\
10.9\end{array}$} & \multirow[t]{2}{*}{$\mathrm{M}$} & \multirow[t]{2}{*}{ SD } \\
\hline & SDA & & & & \\
\hline \multirow[t]{5}{*}{ between army and militants } & DA & 36 & 39.1 & & \\
\hline & UD & 4 & 4.3 & 2.8478 & 1.12840 \\
\hline & A & 42 & 45.7 & & \\
\hline & SA & 0 & 0 & & \\
\hline & Total & 92 & 100.0 & & \\
\hline
\end{tabular}

Table 5 shows that out of 92 respondents $42(42+0), 45.7 \%$ of the respondents agreed with the statement that they feel threats of conflict starting again between army and militants. Forty-six (36+10), 50.0\% of them disagreed with the statement and 4 respondents $(4.3 \%)$ remained undecided. The mean score $2.84, \mathrm{SD}=1.12$ indicates that the majority of the respondents feel threats of conflict starting again between army and militants.

Table 6

Poor security conditions

\begin{tabular}{|c|c|c|c|c|c|}
\hline Statement & Level & $\mathrm{N}$ & $\%$ & $\mathrm{M}$ & SD \\
\hline I am in a chaos due to poor & SDA & 3 & 3.3 & \multirow{6}{*}{3.1304} & \multirow{6}{*}{0.9858} \\
\hline \multirow[t]{5}{*}{ security conditions. } & DA & 30 & 32.6 & & \\
\hline & UD & 11 & 12.0 & & \\
\hline & A & 48 & 52.2 & & \\
\hline & SA & 0 & 0 & & \\
\hline & Total & 92 & 100.0 & & \\
\hline
\end{tabular}

Table 6 shows that out of 92 respondents $48(48+0), 52.2 \%$ of the respondents agreed with the statement that they are in a chaos due to poor security conditions. Thirty-three $(30+3), 35.9 \%$ of the respondents disagreed with the statement and 11 respondents $12.0 \%$ remained undecided. The mean score $3.13, \mathrm{SD}=0.98$ indicates that majority of the respondents are in a chaos due to poor security conditions. 
Table 7

Information regarding unknown attacks creates chaos

\begin{tabular}{|c|c|c|c|c|c|}
\hline Statement & Level & $\mathrm{N}$ & $\%$ & $\mathrm{M}$ & SD \\
\hline The information you receive & SDA & 2 & 2.2 & & \\
\hline regarding unknown attacks create & DA & 7 & 7.6 & & \\
\hline chaos. & UD & 18 & 19.6 & 3.6196 & 0.7680 \\
\hline & A & 62 & 67.4 & & \\
\hline & SA & 3 & 3.3 & & \\
\hline & Total & 92 & 100.0 & & \\
\hline
\end{tabular}

Table 7 shows that out of 92 respondents $65(62+3), 70.7 \%$ of the respondents agreed with the statement that the information they receive regarding unknown attacks create chaos among them. Nine (7+2), 9.8\% of the respondents disagreed with the statement and 18 respondents $19.6 \%$ remained undecided. The mean score $3.61, \mathrm{SD}=0.76$ indicates that majority of the respondents are in a chaos due to receiving information regarding unknown attacks.

Table 8

Military involvement in management

\begin{tabular}{|c|c|c|c|c|c|}
\hline Statement & Level & $\mathrm{N}$ & $\%$ & M & SD \\
\hline involvement & into SDA & 1 & 1.1 & \multirow{6}{*}{3.6196} & \multirow{6}{*}{0.7680} \\
\hline \multirow{5}{*}{ management creates anxiety. } & DA & 9 & 9.8 & & \\
\hline & UD & 18 & 19.6 & & \\
\hline & A & 60 & 65.2 & & \\
\hline & SA & 4 & 4.3 & & \\
\hline & Total & 92 & 100.0 & & \\
\hline
\end{tabular}

Table 8 shows that out of 92 respondents $64(60+4), 69.5 \%$ of the respondents agreed with the statement that military involvement into management creates anxiety. Ten $(9+1), 10.9 \%$ of the respondents disagreed with the statement and 18 respondents $19.6 \%$ remained undecided. The mean score $3.61, \mathrm{SD}=0.76$ indicates that majority of the respondents are in anxiety due to military involvement into educational management.

Table 9

Restrictions of free movement in the area

\begin{tabular}{llllll}
\hline Statement & Level & N & $\%$ & M & SD \\
\hline I feel anxiety due to restrictions of & SDA & 2 & 2.2 & & \\
free movement in the area. & DA & 8 & 8.7 & & \\
& UD & 2 & 2.2 & 3.8913 & 0.8445 \\
& A & 66 & 71.7 & & \\
& SA & 14 & 15.2 & & \\
Total & 92 & 100.0 & & \\
\hline
\end{tabular}

Table 9 shows that out of 92 respondents $80(66+14), 86.9 \%$ of the respondents agreed with the statement that they feel anxiety due to restrictions of free movement in the area. Ten $(8+2), 10.9 \%$ of the respondents disagreed with the statement and 2 respondents $2.2 \%$ remained undecided. The mean score $3.89, \mathrm{SD}=0.84$ indicates that majority of the respondents feel anxiety due to restriction of free movement in the area.

Table 10

Teachers' behavior after rehabilitation

\begin{tabular}{|c|c|c|c|c|c|}
\hline Statement & Level & $\mathrm{N}$ & $\%$ & $\mathrm{M}$ & SD \\
\hline rehabilitation & SDA & 1 & 1.1 & \multirow{6}{*}{3.7500} & \multirow{6}{*}{0.9213} \\
\hline displacement the & DA & 15 & 16.3 & & \\
\hline \multirow{4}{*}{ behavior is non-cooperative. } & UD & 2 & 2.2 & & \\
\hline & A & 62 & 67.4 & & \\
\hline & SA & 12 & 13.0 & & \\
\hline & Total & 92 & 100.0 & & \\
\hline
\end{tabular}

Table 10 shows that out of 92 respondents $74(62+12), 80.4 \%$ of the respondents agreed with the statement that after rehabilitation from displacement the teachers' behavior is non-cooperative. Sixteen $(15+1), 17.4 \%$ of the respondents 
disagreed with the statement and 2respondents $2.2 \%$ remained undecided. The mean score $3.75, \mathrm{SD}=0.92$ indicates that majority of the respondents support that after rehabilitation from displacement the teachers' behavior is noncooperative.

Table 11

Working staff behavior after rehabilitation

\begin{tabular}{|c|c|c|c|c|c|}
\hline Statement & Level & $\mathrm{N}$ & $\%$ & $\mathrm{M}$ & SD \\
\hline rehabilitation & SDA & 1 & 1.1 & \multirow{6}{*}{3.7065} & \multirow{6}{*}{0.9669} \\
\hline displacement the working sta & DA & 18 & 19.6 & & \\
\hline \multirow[t]{4}{*}{ behavior is non-cooperative. } & UD & 0 & 0 & & \\
\hline & A & 61 & 66.3 & & \\
\hline & SA & 12 & 13.0 & & \\
\hline & Total & 92 & 100.0 & & \\
\hline
\end{tabular}

Table11 shows that out of 92 respondents $73(61+12), 79.3 \%$ of the respondents agreed with the statement that after rehabilitation from displacement the working staff behavior is non-cooperative. Nineteen $(18+1), 20.7 \%$ of the respondents disagreed with the statement. The mean score 3.70, SD $=0.96$ indicates that majority of the respondents support that after rehabilitation from displacement the working staff behavior is non-cooperative.

Table 12

Getting irritated due to non-cooperative behavior

\begin{tabular}{llllll}
\hline Statement & Level & N & $\%$ & M & SD \\
\hline I get irritated quick in this scenario. & SDA & 1 & 1.1 & & \\
& DA & 35 & 38.0 & & \\
& UD & 23 & 25.0 & 2.9674 & 0.9072 \\
A & 32 & 34.8 & & \\
SA & 1 & 1.1 & & \\
Total & 92 & 100.0 & & \\
\hline
\end{tabular}

Table 12 shows that out of 92 respondents $33(32+1), 35.9 \%$ of the respondents agreed with the statement that they get irritated quick in this scenario of non-cooperative behavior of working as well as teaching staff. Thirty-sis (35+1), $39.1 \%$ of the respondents disagreed with the statement and 23 respondents $25.0 \%$ remained undecided. The mean score $2.96, \mathrm{SD}=0.90$ indicates that this is debatable statement.

Table 13

Educational managers feel sense of security when military visit their school

\begin{tabular}{llllll}
\hline Statement & Level & N & $\%$ & M & SD \\
\hline We all feel secure when the military SDA & 1 & 1.1 & & \\
visit the school & DA & 26 & 27.2 & & \\
& UD & 8 & 8.7 & 3.4130 & 1.0071 \\
A & 51 & 55.4 & & \\
SA & 7 & 7.6 & & \\
Total & 92 & 100.0 & & \\
\hline
\end{tabular}

Table 13 shows that out of 92 respondents $58(51+7), 63 \%$ of the respondents agreed with the statement that they all feel secure when the military visit the school. Twenty-six (26), 28.3\% of the respondents disagreed with the statement and 8 respondents $8.7 \%$ remained undecided. The mean score $3.41, \mathrm{SD}=1.00$ indicates the majority of the respondents feel secure when the military visit their school.

Table 14

Students sense of security in schools

\begin{tabular}{llllll}
\hline Statement & Level & N & $\%$ & M & SD \\
\hline Students feel sense of security in SDA & 1 & 1.1 & & \\
schools. & DA & 12 & 13.0 & & \\
& UD & 5 & 5.4 & 3.7500 & 0.8467 \\
& A & 65 & 70.7 & &
\end{tabular}


Total $\quad 92 \quad 100.0$

Table 14 shows that out of 92 respondents $74(65+9), 80.5 \%$ of the respondents agreed with the statement that students feel sense of security in schools. Thirteen $(12+1), 14.1 \%$ of the respondents disagreed with the statement and 5 respondents $5.4 \%$ remained undecided. The mean score $3.75, \mathrm{SD}=0.84$ indicates that majority of the respondents support that students feel sense of security in schools.

Table 15

Military visit and teachers feeling

\begin{tabular}{llllll}
\hline Statement & Level & N & $\%$ & M & SD \\
\hline Teachers feel comfortable when & SDA & 1 & 1.1 & & \\
army/Military visit the school. & DA & 67 & 72.8 & & \\
& UD & 10 & 10.9 & 2.4348 & 0.8426 \\
& A & 11 & 12.0 & & \\
& SA & 3 & 3.3 & & \\
& Total & 92 & 100.0 & & \\
\hline
\end{tabular}

Table 15 shows that out of 92 respondents $14(11+3), 15.3 \%$ of the respondents agreed with the statement that teachers feel comfortable when army/Military visit the school. Sixty-eight $(67+1), 73.9 \%$ of the respondents disagreed with the statement and 10 respondents $10.9 \%$ remained undecided. The mean score $2.43, \mathrm{SD}=0.84$ indicate that majority of the respondents disagree with the statement that teachers feel comfortable when army/military visit the school.

Table 16

Students' behavior

\begin{tabular}{|c|c|c|c|c|c|}
\hline Statement & Level & $\mathrm{N}$ & $\%$ & $\mathrm{M}$ & SD \\
\hline rehabilitation & SDA & 1 & 1.1 & \multirow{6}{*}{3.5543} & \multirow{6}{*}{1.0202} \\
\hline displacement the & DA & 23 & 25.0 & & \\
\hline \multirow[t]{4}{*}{ behavior is non-cooperative. } & UD & 2 & 2.2 & & \\
\hline & A & 56 & 60.8 & & \\
\hline & SA & 10 & 10.9 & & \\
\hline & Total & 92 & 100.0 & & \\
\hline
\end{tabular}

Table 16 shows that out of 92 respondents $66(56+10), 71.7 \%$ of the respondents agreed with the statement that after rehabilitation from displacement the students' behavior is non-cooperative. Twenty-four $(23+1), 26.1 \%$ of the respondents disagreed with the statement and 2 respondents $2.2 \%$ remained undecided. The mean score 3.55 , SD $=$ 1.02 indicates that majority of the respondents say that after rehabilitation from displacement the students' behavior is non-cooperative.

\section{Analysis of Interview Data}

Researcher has conducted 24 interviews from the Maliks of Government schools. The conducted interviews of this research were semi-structured in nature. The basic objective of the interview was to find out the problems which were faced by educational managers after rehabilitation. After transcription coding following findings were came out. The following psychological problems indicated by Maliks.

\section{Unclear Circumstances}

Responses collected from the respondents show that circumstances were unclear, there were a lot of difficulties, like houses and schools were completely destroyed. Everyone was very upset and feared because the situation was unclear. Any time unpleasant incident may be faced everywhere by anyone in the area of South Waziristan Agency. Basically the area was war torn and closed for long time and now with new and fresh opening made circumstances unclear. That was creating anxiety, fear and chaos among the respondents.

\section{Fear of being killed}

Responses from the respondents illustrate that in the beginning when the education managers returned they were feeling fear of being killed or injured. They were feeling threats of unknown incidents. 


\section{Tension and anxiety}

Responses show that educational managers were facing tension and anxiety. The education managers were always thinking about the security of schools, teachers and students. The thinking and alertness about security were keeping them in tension and anxiety almost all time.

\section{Fear of missiles and firing}

Responses illustrate that respondents were feeling fear of attacks of missiles and firing at day as well as night times. Missiles were fired by unknown persons and from unknown places any time from that situation respondents were feeling fear threat, anxiety and chaos all the day and night.

\section{Fear of mining bombs}

Responses collected from the respondents explain that respondents were feeling fear of mining bombs concealed in the area. They told that some people and many animals were blown up by mining bombs. If bomb blasts the military raid on the nearby houses or villages to the incident location. Whole village was considering responsible for that and was taken investigation from the villagers and was panelized for no sin or crime that makes the community worry. The respondents said that they feeling fear of blowing off by mining bombs as well as investigation.

\section{Past traumatic events}

Responses collected from the respondents show that the past events which were witnessed there in the area of SWA was imprinted in the minds of the people and along that the ruined houses and buildings were also creating fear, anxiety, threat and chaos. The losing lives of relatives, friends and family members were creating anxiety. The past traumatic events witnessed there in the area were creating anxiety, fear and chaos among the educational managers.

\section{Buildings and houses are destroyed into wreckage}

Responses from the respondents illustrate that the wreckage of the destroyed building and houses is presenting the atmosphere of ruins and war zone. The destructed scenery of the area is creating fear, anxiety and chaos in respondents.

\section{Having no defense and security instruments/weapons in school for security}

Responses of the respondents show that the educational institutions do not have any security guard and also the school managers are not permitted to keep any weapon for security proposes. Therefore educational managers are feeling threats of insecurity from militants as well as attacks of wild beasts.

\section{Fear of students as victimized by militants.}

Responses from the data show that educational managers were feeling fear of victimization of the students. They were feeling fear of putting explosive materials in the bags of the students by militants and occurrence of unpleasant incident. Educational managers as well as their parents give security instructions which create anxiety and insecurity among the students.

\section{News and talk about terrorism.}

Responses explain that the news and talks regarding the incidents faced by the community from terrorism create anxiety and fear among the respondents.

\section{No means of communication like mobile of phone.}

Responses from the respondents illustrate that when educational managers go to perform their duty in the area they are cut off or disconnected from all their family, friends, relatives, and the department due to non-availability of any communication channels in the area of SWA. There is no mobile network in the area and there is only one public telephone arranged by army with scheduled time for calling and this is on distance from educational institutions. This isolation and disconnection from contacts create anxiety and chaos in the people.

\section{A very small population moved back.}


Responses explain that very small population moved back in the area declared opened after military operation. Population does not move due to destroyed houses and non-availability of facilities. This is creating fear and threat among the respondents.

\section{Restrictions and instructions by military.}

Responses show that military restricts the community from free movement in the area. Areas are specified by the military for movement and also instructions for movement in the area regarding time schedule and specified area are given to the community. These restrictions create anxiety, insecurity and chaos in the respondents.

\section{Conclusions}

On the basis of the findings obtained through data from educational managers conclusions regarding psychological problems of educational managers were drawn and prioritized as under:

It revealed from the data that area is still occupied by military. It was concluded that majority of the people still feel fear due to previous evidences of terrorism and concealed mining bombs in the area also the past traumatic events create chaos. It is clear from the data and findings that after rehabilitation from displacement the teaching and nonteaching staff as well as students' behavior are non-cooperative. It was concluded that threats of starting conflict again between army and militants and the educational managers getting irritated quickly at the non-cooperative behavior of teaching and non-teaching staff are debatable statements. It was revealed from the data that most of educational managers receive information regarding unknown attacks create chaos in them. It was concluded that majority of the educational managers feel anxiety due to restrictions on free movement in the area.

This study has provided us useful as well as valuable results through which education department, military and administration may resolve the problems related to psychological basis and may restore prosperous life in the area.

\section{References}

Ahmad S. (2012). The Taliban and Girls' Education in Pakistan and Afghanistan - with a case study of the situation in the Swat District, (Master thesis, Department of Sociology, University of Lund, Sweden) Retrieved from, https://lup.lub.lu.se/luur/download?func=downloadFile\&recordOId=3160037\&fileOId=3160041

Ali, A. (2010). Militancy and Socio-economic Problems: A Case Study of Pakistan. National Institute of Strategic studies (NIPS), Islamabad. NDU Journal, 1 (1).

Awan, N. (2013). Education in FATA. Pakistan Annual Research Journal Vol-49 Retrieved from, https://www.pscpesh.org/PDFs/PJ/Volume_49/12-Paper\%20by\%20Nazakat.pdf

Aziz, M., Bloom, D. E., Humair, S., Jimenez, E., Rosenberg, L., \& Sathar, Z. (2014). Education system reform in Pakistan: why, when, and how? (No. 76). IZA Policy Paper.

Codebook (2016). Global Terrorism Database. "Global Terrorism Database Codebook." June 2016. Page 9. Accessed November 13, 2016. Retrieved from https://www.start.umd.edu/gtd/downloads/Codebook.pdf.

EMIS Cell South Waziristan Agency 2016.

FATA Development Statistics 2012.

Hussain, N. (2016). Why Terrorists Attack Education. The Express Tribune. Accessed November, 13. Retrieved on 13/11/2016 from http://labs.tribune.com.pk/attack-on-education/.

Javaid, U. (2015). Operation Zarb-e-Azb: A Successful Initiative to Curtail Terrorism. South Asian Studies (1026$678 X), 30(2)$.

Khan H. (2013). Pakistan's Contribution to Global War on Terror after 9/11, IPRI Journal XIII, No.1 (Winter 2013): $37-56$

Khan, S., \& Seltzer, A. (2016). The Impact of Fundamentalist Terrorism on School Enrolment: Evidence from NorthWestern Pakistan, 2004-09. The Institute for the Study of Labor 10168: 5.

Malhotra A. (2017). A Global Analysis of the Effect of Terrorism on Primary Education Enrollment, Wshington, DC

Masood T. (2012). Pakistan Fight Against Terrorism, Defense Against Terrorism Review, Vol. 4, No. 1, Spring \& Fall 2012, pp, 13-30. ISSN: 1307-9190

Mehsud I.T \& Israr H (2014). The South Waziristan Agency: A Brief Status Report. SISA Report No.21-2014

Naqvi, A. A., Khan, S. Z., \& Ahmad, Z. (2012). The Impact of Militancy on Education in FATA. TIGAH, A Journal for Peace and Development, 2, 22-40. 
Saqib M, Ahmad S. M. (2014). Root Causes of Low Female Literacy in FATA Pakistan: (A Case Study of Jalozai Camp),International Journal of Academic Research in Business and Social Science, Vol. 4, No. 3, ISSN: 22226990, DOI: 10.6007/IJARBSS/v4-i3/728, URL: http://dx.doi.org/10.6007/IJARBSS/v4-i3/728

Sultana, R. (2015). Major Threats to Pakistan in the Wake of US Withdrawal from Afghanistan: The Case of FATA and KP. FWU Journal of Social Sciences, 1(1), 64.

UNESCO (2010). "Education under Attack". http://unesdoc.unesco.org/images/0018/ 001868/186809e.pdf retrieved on $31 / 05 / 2016$.

Wazir Z.U. (2014). Indigenous Factors Responsible for the Rise of Militancy in FATA, Department of Political Science, Abdul Wali Khan University, Mardan, Khyber-Pakthunkhwa, Pakistan, Middle-East Journal of Scientific Research 22 (9), 1320-1330, ISSN 1990-9233, DOI: 10.5829/idosi.mejsr.2014.22.09.22040 